\title{
Efficiency of Islamic Rural Banks (BPRS) in East Java Province, Indonesia
}

\author{
Endiarjati Dewandaru Sadono ${ }^{1}$
}

\begin{abstract}
This study aims to measure technical efficiency and identify factors that affect technical inefficiency of Islamic rural banks (BPRS) in East Java Province, Indonesia. We also want to test whether BPRS operating in districts are more efficient than those operating in cities. Data that we use are unbalanced panel data from 2011 until 2016 using stochastic frontier analysis. This study has successfully identified that the technical efficiency of BPRS operation is 90.12 percent. It means that there is still about 9.88 percent that can be optimized to improve their performance. Factors that cause technical inefficiency are Capital Adequacy Ratio (CAR) and Net Performing Financing (NPF). To improve technical efficiency of BPRS operations, the effort that must be made is to ensure each BPRS has sufficient capital stock to be channeled into loans. In addition, BPRS should also ensure the risks of bad loans are minimum.
\end{abstract}

Keywords: Islamic rural bank (BPRS), Stochastic Frontier Analysis, Technical Efficiency

Abstrak. Studi ini bertujuan untuk mengukur efisiensi teknis dan mengidentifikasi faktorfaktor apa saja yang mempengaruhi inefisiensi teknis pada Bank Pembiayaan Rakyat Syariah (BPRS) di Provinsi Jawa Timur. Studi ini juga berupaya menguji apakah BPRS yang beroperasi di kabupaten lebih efisien daripada BPRS yang beroperasi di kota. Data yang digunakan adalah data unbalanced panel dari 2011 hingga 2016 dengan menggunakan stochastic frontier analysis. Studi ini berhasil mengidentifikasi bahwa efisiensi teknis pada operasional BPRS adalah 90,12 persen. Artinya, masih ada 9,88 persen yang dapat dioptimalkan untuk memperbaiki kinerja BPRS. Faktor yang menyebabkan inefisiensi teknis adalah Capital Adequacy Ratio (CAR) dan Net Performing Financing (NPF). Untuk meningkatkan efisiensi teknis pada operasional BPRS, upaya yang harus dilakukan adalah memastikan setiap BPRS mempunyai persediaan modal yang dapat dipinjamkan. Selain itu, $B P R S$ juga harus meminimalkan risiko kredit macet.

Kata kunci: BPRS, Stochastic Frontier Analysis, efisiensi teknis

${ }_{1}$ Department of Economics, Faculty of Economics and Business Universitas Gadjah Mada. 


\section{Introduction}

Indonesian rural bank namely Bank Perkreditan Rakyat (BPR) is a part of the banking system that plays a significant role in the economic development in Indonesia. Along with the growing of BPR, Bank Pembiayaan Rakyat Syariah (BPRS) was also born. BPRS is a bank of people financing that operates based on sharia principles. The special purpose of BPRS, which is providing financing and giving assistance to low-income communities and Micro, Small and Medium Enterprises (UMKM) to reduce poverty and achieve public welfare, often faces competition with existing BPR and other microfinance institutions making UMKM as their target market. Therefore, BPRS is required to operate efficiently and as well as possible in order to remain able to compete in the banking industry.

With such a background, this study aims to measure how efficient the BPRS operates and to identify what factors are causing inefficiencies in BPRS operations. In addition, this study also aims to identify whether BPRS operating in the district are more efficient than those in the city. The study conducted by Sadono (2017) proved that Indonesian government in districts area operate more efficiently than in cities. So, this study attempts to test whether the districts are supported by efficient BPRS.

Over the last few years, there have been many empirical studies measuring the technical efficiency of banking industry with stochastic frontier analysis. Some of these studies are by Bhattacharyya and Pal (2013), Hasan et al. (2012), Hosen and Muharri (2013), Ngan (2014), Tahir and Haron (2008) and Zuhroh et al. (2015).

This study is different from previous studies because only focuses in one region, East Java Province. The majority of previous studies focus on sharia banking on national level. There are several reasons why we use BPRS in the East Java Province as the object. First, majority of East Java residents are moslems, 94.35 percent according to BPS (2017). Second, the financial and 
insurance sectors contributions to Gross Regional Domestic Product (GRDP) in East Java Province are above 15 percent (see Figure 1). BPRS is one of the financial institutions that have a major contribution to this sector. So, BPRS is considered the most suitable financial intermediaries to serve the interests of UMKM and residents there.

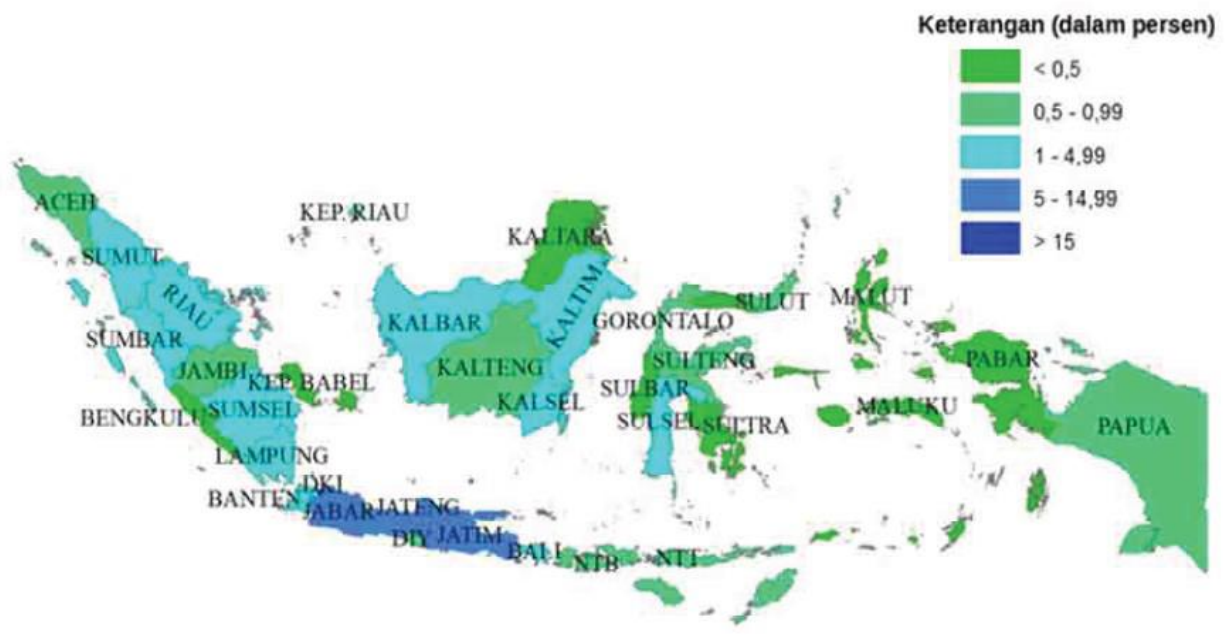

Figure 1. Financial and Insurance Sector Contributions to GRDP by Province, $2015(\%)$

Source: BPS (2016)

\section{Literature Review}

Using data from 1989 until 2009, Bhattacharyya and Pal (2013) found that conventional bank's technical efficiency in India is 64 percent. Another study by Ngan (2014) found that there are decreasing trend of 45 conventional bank's cost efficiency and profit efficiency in Vietnam from 2007 until 2012. In terms of profit, public commercial banks are more efficient than private commercial and foreign banks. But in terms of cost, international banks are the most efficient.

Tahir and Haron (2008) used stochastic frontier analysis to estimate 22 conventional banks (9 domestic banks and 13 foreign banks) in Malaysia from 2000 until 2006. They found that technical efficiency is 81 percent. This study is 
consistent with Hasan et al. (2012), which found that conventional bank's technical efficiency in Malaysia was 94 percent in 2005 until 2010. In addition, Tahir and Haron (2008) found that domestic banks are more efficient than foreign banks.

Zuhroh et al. (2015) used all sharia banking data and 19 conventional banks in Indonesian Stock Exchange (IDX) from 2004:3 until 2014:4. They found that sharia bank's cost efficiency was lower than conventional bank, but sharia bank's technical efficiency was higher than conventional bank. This is because sharia banks have lower allocative efficiency than conventional banks. Factors which influence cost efficiency are managerial skills, equity, net performing financing (NPF), industry competition and loan to deposits ratio (LDR).

Hosen and Muharri (2013) employed stochastic frontier analysis with asset approach to analyze efficiency of 59 BPRS from 2011:Q2 until 2012:Q4. They found that the technical efficiency was 81.41 percent. In addition, conventional bank's efficiency is higher than BPRS. Another study by Sadono and Fatahillah (2016) found that technical efficiency of BPRS in Special Region of Yogyakarta was 82.93 percent.

\section{Method}

This study wants to measure the technical efficiency of a decision making unit with Stochastic Frontier Analysis (SFA). The SFA used in this study refers to SFA developed by Aigner, Lovell and Schmidt (1977) and Meeusen and van den Broeck (1977). According to Aigner, Lovell and Schmidt and Meeusen and van den Broeck (1977), the error term consists of the following two independent components:

$$
\varepsilon_{i}=V_{i}-U_{i}
$$

in which $V$ is a two-sided error term that explains statistical noise and $U$ is an one-sided error term that explains technical inefficiency. $V$ records random variation in the output that caused by factors outside the firm's control, such as 
measurement error in the output, weather and industrial action (Schmidt and Lovell, 1979; Battese, 1992). $U$ is assumed to have a distribution which is independent of $V$. This component explains that each output of the firm should be equal or less than the frontier. Any deviations that occur are influenced by factors that can be controlled by the firm, such as technical and economic inefficiency, as well as the producers and workers motivation and effort (Sadono, 2015). The structure of error term shaped like this because, by definition, inefficiency should not be negative (Fries and Taci, 2005).

SFA not only allows us to measure the rate technical inefficiency, but also technical efficiency and factors that cause it at a series of production function. SFA used in this study can be written as follows.

$$
Y_{i}=f\left(X_{i} ; \beta\right)+V_{i}-U_{i}
$$

where $Y$ is the output, $X$ is an actual input vector, $\beta$ is a parameter vector of the production function. Stochastic frontier production function explained by $f(X ; \beta)$ and is a measure of maximum output that can potentially achieved for most of the input vector $\mathrm{X}$. Both $\mathrm{V}$ and $\mathrm{U}$ cause the actual production deviating from the frontier. Technical inefficiency $(\mathrm{U})$ can be measured and factors that cause can be measured through inefficiency effects model. Usually the factors affecting technical inefficiency are the socio-economic characteristics inherent in the decision making units. The stochastic frontier model above is estimated using Maximum Likelihood Methods (MLE).

In this study, we use all BPRS data in East Java Province that is obtained from Otoritas Jasa Keuangan (OJK). But, this study uses unbalanced panel data because not all BPRS data are available from the beginning of 2011. This is because not all BPRS had reported their financial statements to OJK in 2011. Since this study uses parametric approach, all data is assumed to be normally distributed. It is also in accordance with the stochastic frontier approach estimation procedure as proposed by Aigner, Lovell and Schmidt (1977). We 
also assume that the technical inefficiency exists on the operation of BPRS in East Java Province.

Stochastic frontier model in this study are modified from Tahir and Haron (2008), Hasan et al. (2012), Bhattacharyya and Pal (2013), and Sadono and Fatahillah (2016), which are:

$$
\ln T E A_{i t}=\beta_{0}+\beta_{1} \ln T D_{i t}+\beta_{1} \ln O C_{i t}+V_{i t}-U_{i t}
$$

where,

TEA = Total Earning Assets, which is the sum of account in Bank Indonesia, account in another bank, muräbahah credit, salam credit, istishna' credit, mudhārabah financing, musyārakah financing, ijārah, qardh and multiservice credit.

$\mathrm{TD}=$ Total Deposits, which is the sum of income from wadiah account, mudhārabah account and mudhārabah deposits

$\mathrm{OC}=$ Operational Costs

$\mathrm{U} \quad=$ Technical Inefficiency, which is a non-negative random variable

$\mathrm{V}=$ Statistical Noise, which is normal distributed and independent from $\mathrm{U}$

In this study, we expect that CAR, NPF, ROA, ROE and Dummy of District/City influence technical inefficiency of BPRS operation in East Java Province. These factors can be expressed through inefficiency effects model. Our inefficiency effects model are modified from Bhattacharya and Pal (2013), Firdaus and Hosen (2013), and Sadono and Fatahillah (2016). Therefore, the inefficiency effects model can be written as follows:

$$
U_{i t}=\alpha_{0}+\alpha_{1} \ln C A R_{i t}+\alpha_{2} \ln N P F_{i t}+\alpha_{3} \ln R O A_{i t}+\alpha_{4} \ln R O E_{i t}+\alpha_{5} D C C
$$

where CAR is the Capital Adequacy Ratio, NPF is the Net Performing Financing, ROA is the Return on Asset, ROE is the Return on Equity and DCC is the Dummy of District/City. Our stochastic frontier model and inefficiency effects model are estimated using MLE by STATA versions 13 software. 


\section{Result and Discussion}

Obviously, there are 593 observations in our study, but because some observations like on ROA and ROE have a negative value and because STATA cannot estimate negative value observations, our observations remain only 420 , which includes 30 BPRS. These 30 BPRS are spread in 5 cities and 14 districts. Table 1 below shows the distribution of BPRS in each city and district. From this table, it can be seen that each district/city have one until two BPRS on average in their region, except Pasuruan District which has four BPRS in its region.

Table 1. Distribution of BPRS in East Java Province

\begin{tabular}{ll}
\hline \multicolumn{1}{c}{ District/City } & \multicolumn{1}{c}{ Name of BPRS } \\
\hline Gresik District & 1. BPRS Amanah Sejahtera \\
& 2. BPRS Mandiri Mitra Sukses \\
Sidoarjo District & 1. BPRS Baktimakmur Indah \\
& 2. BPRS Annisa Mukti \\
Jombang District & 1. BPRS Lantabur Tebuireng \\
Sampang District & 1. BPRS Bakti Artha Sejahtera \\
Pamekasan District & 1. BPRS Sarana Prima Mandiri \\
Sumenep District & 1. BPRS Bhakti Sumekar \\
Malang District & 1. BPRS Bhakti Haji \\
& 2. BPRS Bumi Rinjani Kepanjen \\
Pasuruan District & 1. BPRS Al Hidayah \\
& 2. BPRS Daya Artha Mentari \\
& 3. BPRS Jabal Tsur \\
Probolinggo District & 4. BPRS Ummu \\
Kediri District & 1. BPRS Bumi Rinjani Probolinggo \\
& 1. BPRS Artha Pamenang \\
Magetan District & 2. BPRS Rahma Sharia \\
Ponorogo District & 1. BPRS Sharia Magetan \\
Lamongan District & 1. BPRS Al Mabrur Babadan \\
Situbondo District & 1. BPRS Madinah \\
Batu City & 1. BPRS Situbondo \\
& 1. BPRS Bumi Rinjani Batu \\
& 2. BPRS Bumi Rinjani \\
&
\end{tabular}


TIFBR | Tazkia Islamic Finance and Business Review

\begin{tabular}{ll}
\multicolumn{1}{c}{ District/City } & \multicolumn{1}{c}{ Name of BPRS } \\
\hline Surabaya City & 1. BPRS Jabal Nur \\
& 2. BPRS Karya Mugi Sentosa \\
Mojokerto City & 1. BPRS Kota Mojokerto \\
Malang City & 1. BPRS Bumi Rinjani Malang \\
& 2. BPRS Mitra Harmoni Kota Malang \\
Kediri City & 1. BPRS Tanmiya Artha \\
\hline & Source: OJK (2017)
\end{tabular}

Table 2 below shows the descriptive statistics of all variable in this study. The unit measurement, the number of observation, mean, standard deviation, minimum and maximum value off all variables in this study are summarized in this table. It can be seen from table 2 that there are big differences between variables. In one point of time, a BPRS can earn IDR 510.62 billion of assets, but in another time, a BPRS can only earn IDR 2.36 billion.

Table 2. Descriptive Statistics

\begin{tabular}{|c|c|c|c|c|c|c|}
\hline Variable & Unit & Obs. & Mean & Std. Dev & Min. & Max. \\
\hline $\begin{array}{l}\text { Total Earning } \\
\text { Assets }\end{array}$ & Million Rupiah & 420 & $39,899.37$ & $73,630.83$ & 2,358 & 510,619 \\
\hline Total Deposit & Million Rupiah & 420 & $21,918.65$ & $35,678.73$ & 1,505 & 297,640 \\
\hline $\begin{array}{l}\text { Operational } \\
\text { Cost }\end{array}$ & Million Rupiah & 420 & 2,180 & 3,091 & 102 & 25,161 \\
\hline CAR & Percent & 420 & 49.03 & 92.16 & 0.27 & 613.21 \\
\hline NPF & Percent & 420 & 6.766 & 5.31 & 0.14 & 41.42 \\
\hline ROA & Percent & 420 & 4.64 & 9.31 & 0.01 & 106.93 \\
\hline ROE & Percent & 420 & 37.98 & 69.76 & 0.06 & 728.05 \\
\hline DDC & 0: District, 1: City & 420 & 0.24 & 0.42 & 0 & 1 \\
\hline
\end{tabular}

Table 3 below shows the correlation between independent variables in this study. From this table, it appears that there are no multicollinearities between these variables. This occurs because no correlation value exceeds 0.8 . A relationship between variables are said not to be multicollinear if the correlation value is not higher than 0.8 (Gujarati, 2009: 325). 
TIFBR | Tazkia Islamic Finance and Business Review

Table 3. Correlations between Independent Variables

\begin{tabular}{|c|c|c|c|c|c|c|c|}
\hline & $\operatorname{lnTD}$ & $\operatorname{lnOC}$ & InCAR & $\operatorname{lnNPF}$ & $\ln R O A$ & $\ln R O E$ & DDC \\
\hline $\operatorname{lnTD}$ & 1.000 & & & & & & \\
\hline $\operatorname{lnOC}$ & 0.7804 & 1.000 & & & & & \\
\hline InCAR & -0.0731 & 0.0405 & 1.000 & & & & \\
\hline $\operatorname{lnNPF}$ & 0.0641 & 0.0087 & -0.0244 & 1.000 & & & \\
\hline $\ln R O A$ & 0.0693 & 0.1229 & 0.0716 & -0.1349 & 1.000 & & \\
\hline $\ln R O E$ & 0.3664 & 0.3169 & -0.2078 & -0.1332 & 0.7645 & 1.000 & \\
\hline DDC & -0.1896 & -0.2269 & -0.1527 & 0.0329 & -0.0855 & -0.0629 & 1.000 \\
\hline
\end{tabular}

Source: Author's calculation

Table 4 below shows the results of stochastic frontier model and inefficiency effects model estimation with MLE. The lambda is obtained by subtracting 1 with sigma_v. The result was $1-0.315$, which is 0.685 . It means that error in the model caused more by technical inefficiency.

Table 4. Results of Stochastic Frontier Model and Inefficiency Effects Model

\begin{tabular}{|c|c|c|c|}
\hline \multicolumn{4}{|c|}{ Stochastic Frontier Model } \\
\hline \multicolumn{4}{|c|}{ Dependent Variable: Total Earning Assets } \\
\hline \multicolumn{4}{|c|}{ Independent Variable: } \\
\hline Constant & $\begin{array}{c}0.881^{* * *} \\
(0.260)\end{array}$ & & \\
\hline $\operatorname{lnTD}$ & $\begin{array}{c}0.697^{* * *} \\
(0.024)\end{array}$ & & \\
\hline $\operatorname{lnOC}$ & $\begin{array}{c}0.333^{\star * *} \\
(0.025)\end{array}$ & & \\
\hline \multicolumn{4}{|c|}{ Inefficiency Effects Model } \\
\hline Constant & $\begin{array}{c}0.355 \\
(1.837)\end{array}$ & $\ln R O E$ & $\begin{array}{c}-0.098 \\
(0.286)\end{array}$ \\
\hline $\operatorname{lnCAR}$ & $\begin{array}{c}-1.760^{* * *} \\
(0.419)\end{array}$ & DDC & $\begin{array}{c}-34.324 \\
(1325.829)\end{array}$ \\
\hline $\operatorname{lnNPF}$ & $\begin{array}{c}0.892^{*} \\
(0.489)\end{array}$ & Log likelihood & -124.075 \\
\hline $\ln R O A$ & $\begin{array}{c}0.108 \\
(0.359)\end{array}$ & Lambda & 0.685 \\
\hline DDC & $\begin{array}{c}-34.324 \\
(1325.829)\end{array}$ & & \\
\hline
\end{tabular}

Source: Author's calculation

Notes: *significant at $\alpha=10 \%,{ }^{* *}$ significant at $\alpha=5 \%,{ }^{* * *}$ significant at $\alpha=1 \%$ level 
It can be seen from table 4 that Total Deposits (TD) and Operational Cost (OC) has a positive and significant impact on Total Earning Assets (TEA). If total deposits increase by 1 percent, then total earning assets increase by 0.697 percent, ceteris paribus. If operational costs increase by 1 percent, then total earning assets increase by 0.333 percent, ceteris paribus.

Capital Adequacy Ratio (CAR) has a negative and significant effect on technical inefficiency. In other words, capital adequacy ratio has a positive effect on technical efficiency. If the value of CAR is higher, the technical efficiency of BPRS operations also get higher, ceteris paribus. In other hand, Net Performing Loans (NPF) has a positive and significant effect on technical inefficiency. In other words, net performing loans have a negative effect on technical efficiency. If the value of NPF decreases, the technical efficiency of BPRS operations increases, ceteris paribus. The dummy of district/city variable does not significantly affect technical efficiency. Thus, our study is different from Sadono (2017), because there are no significant differences between BPRS that operating in districts than those that operate in cities. Because the observation we use are only in East Java Province, while the study by Sadono (2017) use all districts/cities in Indonesia in 2015 as their observations.

To improve technical efficiency of BPRS operations in East Java Province, the effort that must be made is to ensure each BPRS has sufficient capital stock to be channeled into loans. In addition, BPRS should also ensure the risks of bad loans are minimum. Thus, BPRS can optimize their loans distribution and make their customers more confident about BPRS financial performance. This study is different from Sadono and Fatahillah (2016), who find total assets and ROE as the factors that cause technical inefficiency of BPRS operation in Special Region of Yogyakarta during 2012-2016.

Table 5. Mean Technical Efficiency

\begin{tabular}{cccccc}
\hline Variable & Observation & Mean & Std. Deviation & Minimum & Maximum \\
\hline $\mathrm{U}$ & 420 & 0.0988 & 0.0993 & 0.0000 & 0.5972 \\
\hline \multicolumn{5}{c}{ Source: Author's calculation } \\
\end{tabular}


Table 5 above shows the mean technical inefficiency of our estimation. The mean technical inefficiency is 9.88 percent, so the mean technical efficiency is 90.12 percent. There is 9.88 percent opportunity that can be optimized to reach the most efficient operation of BPRS in East Java Provinces.

Table 6. Mean Technical Efficiency of each BPRS

\begin{tabular}{|c|c|c|}
\hline Number & Name of BPRS & Mean Technical Efficiency \\
\hline 1 & BPRS Amanah Sejahtera & 71.22 \\
\hline 2 & BPRS Mandiri Mitra Sukses & 84.92 \\
\hline 3 & BPRS Baktimakmur Indah & 95.57 \\
\hline 4 & BPRS Annisa Mukti & 95.75 \\
\hline 5 & BPRS Unawi Barokah & 95.67 \\
\hline 6 & BPRS Lantabur Tebuireng & 74.89 \\
\hline 7 & BPRS Bakti Artha Sejahtera & 92.93 \\
\hline 8 & BPRS Sarana Prima Mandiri & 75.88 \\
\hline 9 & BPRS Bhakti Sumekar & 96.48 \\
\hline 10 & BPRS Bhakti Haji & 84.39 \\
\hline 11 & BPRS Bumi Rinjani Kepanjen & 85.10 \\
\hline 12 & BPRS Al Hidayah & 83.59 \\
\hline 13 & BPRS Daya Artha Mentari & 76.67 \\
\hline 14 & BPRS Jabal Tsur & 81.32 \\
\hline 15 & BPRS Ummu & 85.19 \\
\hline 16 & BPRS Bumi Rinjani Probolinggo & 75.84 \\
\hline 17 & BPRS Artha Pamenang & 85.13 \\
\hline 18 & BPRS Rahma Sharia & 87.34 \\
\hline 19 & BPRS Sharia Magetan & 98.32 \\
\hline 20 & BPRS Al Mabrur Babadan & 91.78 \\
\hline 21 & BPRS Madinah & 88.23 \\
\hline 22 & BPRS Situbondo & 98.49 \\
\hline 23 & BPRS Bumi Rinjani Batu & 100.00 \\
\hline 24 & BPRS Bumi Rinjani & 100.00 \\
\hline 25 & BPRS Jabal Nur & 100.00 \\
\hline 26 & BPRS Karya Mugi Sentosa & 100.00 \\
\hline 27 & BPRS Kota Mojokerto & 100.00 \\
\hline 28 & BPRS Bumi Rinjani Malang & 100.00 \\
\hline 29 & BPRS Mitra Harmoni Kota Malang & 100.00 \\
\hline 30 & BPRS Tanmiya Artha & 100.00 \\
\hline
\end{tabular}

Source: Author's calculation 
In addition, table 6 above shows the mean technical efficiency of each BPRS. From this table, it can be shown that the most efficient BPRS is BPRS Kota Mojokerto, BPRS Bumi Rinjani Batu, BPRS Bumi Rinjani, BPRS Jabal Nur, BPRS Karya Mugi Sentosa, BPRS Bumi Rinjani Malang, BPRS Mitra Harmoni kota Malang, and BPRS Tanmiya Artha (99.99 percent), while the most inefficient is BPRS Amanah Sejahtera (71.2 percent).

\section{Conclusion}

This study aims to identify the technical efficiency of BPRS operation in East Java Province during 2011-2016. This objective is achieved with the identification of technical efficiency by 90.12 percent. It means that there is 9.88 percent of opportunities that can be optimized to achieve the most efficient operational level. The most efficient BPRS is BPRS Kota Mojokerto (99.99 percent), while the most inefficient is BPRS Amanah Sejahtera (71.2 percent). In addition, this study also aims to analyze the factors that cause technical inefficiency of BPRS operations. We successfully find that Capital Adequacy Ratio (CAR) and Net Performing Financing (NPF) are factors that cause technical inefficiency. To improve technical efficiency of BPRS operations, the effort that must be made is to ensure each BPRS has sufficient capital stock to be channeled into loans. In addition, BPRS should also ensure the minimum risks of bad loans.

Lastly, this study also aims to identify whether BPRS operating in the district are more efficient than those in the city. This objective is not successfully done. This is because the observation that we use are only in East Java Province, while the study by Sadono (2017) uses all districts/cities in Indonesia in 2015 in his observation. Therefore, to test whether BPRS that operate in district are more efficient than those that operate in city, the observations for further sudies might use BPRS in Java Island or Indonesia. 


\section{References}

Aigner, D. J., C. A. K. Lovell, and P. Schmidt. (1977). Formulation and Estimation of Stochastic Frontier Production Models. Journal of Econometrics, Vol. 6: 21-37.

Battese, George E. (1992). Frontier Production Functions and Technical Efficiency: A Survey of Empirical Applications in Agricultural Economics. Agricultural Economic, Vol. 7: 185-208.

Bhattacharyya, Aditi, and Sudeshna Pal. (2013). Financial Reforms and Technical Efficiency in Indian Commercial Banking: A Generalized Stochastic Frontier Analysis. Review of Financial Economics, Vol, 22: 109-117.

BPS. (2016). Tinjauan Regional Berdasarkan PDRB Kabupaten/Kota 2011-2015, Buku 5: Pulau Nusa Tenggara, Maluku dan Papua. Jakarta: Badan Pusat Statistik.

BPS. (2017). Jawa Timur Province in Figures 2016. Surabaya: Badan Pusat Statistik Provinsi Jawa Timur.

Charnes, A., W. W. Cooper, and E. Rhodes. (1978). Measuring the Efficiency of Decision Making Units. European Journal of Operational Research, Vol. 2: 429-444.

Farell, Michael J. (1957). The Measurement of Productive Efficiency, Journal of the Royal Statistical Society, Vol. 120: 253-290.

Firdaus, M. F., and M. N. Hosen. (2013). Efficiency of Islamic Banks Using TwoStage Approach of Data Envelopment Analysis. Bulletin of Monetary, Economics and Banking: 155-176.

Fries, Steven., and Anita Taci. (2005). Cost efficiency of banks in transition: Evidence from 289 banks in 15 post-communist countries. Journal of Banking and Finance, Vol. 29: 55-81.

Gujarati, Damodar N., and Dawn C. Porter. (2009). Basic Econometrics Fifth Edition. New York: McGraw-Hill.

Hasan et al. (2012). A Cobb-Douglas Stochastic Frontier Model on Measuring Domestic Bank Efficiency in Malaysia. Plos One, Vol. 7: 1-5.

Hosen, Muhamad N., Syafaat Muharri. (2013). Efficiency of he Sharia Rural Bank in Indonesia Lead to Modified Camel. International Journal of Academic Researh in Economics and Management Sciences, Vol. 2: 3453.

Kumbhakar, Subal C., and C. A. Knox Lovell. (2000). Stochastic Frontier Analysis. Cambridge University Press. 
Lind, D. A., W. G. Marchal., and S. A. Wathen. (2012). Statistical Techniques in Business and Economics 15th Edition. New York: McGraw Hill.

Meeusen, Wim., and Julien van den Broeck. (1977). Efficiency Estimation from Cobb-Douglas Production Function with Composed Error. International Economic Review, Vol. 18: 435-444.

Ngan, Le T. T. (2014). Profit and Cost Efficiency Analysis in Banking Sector: A Case of Stochastic Frontier Approach for Vietnam. Journal of Knowledge Management, Economics and Information Technology, Vol. 4: 1-17.

OJK. (2017). Laporan Keuangan Perbankan. Retrieved from: http:/ / www.ojk.go.id/kanal/perbankan/data-danstatistik/laporan-keuangan-perbankan/Default.aspx

Sadono, Endiarjati D. (2015). Penerapan Fungsi Produksi Cobb-Douglas dalam Menganalisis Technical Efficiency Petani Bawang Merah di Desa Buahan, Kecamatan Kintamani, Kabupaten Bangli Pada Musim Panen 2015. Bachelor Thesis. Faculty of Economics and Business Universitas Gadjah Mada.

Sadono, Endiarjati D., and Haydar H. Fatahillah. (2016). Stochastic Frontier Approach untuk Menganalisis Technical Efficiency Bank Pembiayaan Rakyat Sharia (BPRS) di Provinsi Daerah Istimewa Yogyakarta, 20112016. Proceedings of Forum Riset Ekonomi dan Keuangan Sharia, September 6-8, 2016, Mataram University, Nusa Tenggara Barat.

Sadono, Endiarjati D. (2017). Stochastic Frontier Approach untuk Menganalisis Technical Efficiency Pemerintah Daerah Kabupaten/Kota di Indonesia 2015. Thesis. Magister Ekonomika Pembangunan Faculty of Economics and Business Universitas Gadjah Mada.

Schmidt, P., and C. A. K. Lovell. (1979). Estimating Technical and Allocative Inefficiency Relative to Stochastic Production and Cost Frontiers. Journal of Econometrics, Vol. 9: 343-366.

Tahir, Izah M., and Sudin Haron. (2008). Technical Efficiency of the Malaysian Commercial Banks: A Stochastic Frontier Approach. Banks and Bank Systems, Vol. 3: 65-72.

Zuhroh, Idah et al. (2015). Cost Efficiency of Islamic Banks in Indonesia - A Stochastic Frontier Analysis. Procedia - Social and Behavioral Science, Vol. 211: 1122-1131. 